\title{
The Aspect Of Morphological Structures In English Textbook For Senior High School On Tenth Grade Student's
}

\author{
Ferdias Prihatnasari \\ Fakultas Bahasa Inggris Universitas Bina Sarana Informatika \\ ferdias.fps@bsi.ac.id
}

\author{
Cara Sitasi: \\ Prihatnasari, F. (2019). The Aspect Of Morphological Structures In English Textbook For Senior High School \\ On Tenth Grade Student's. Wanastra, 11(1), 71-88.
}

\begin{abstract}
This research analyzes about the aspect of morphological structures in textbooks used by senior high school, English Zone and English book. The reason why this topic is chosen since the curiosity demands to know whether the textbooks used in school is fulfilled or not in terms of morphological structure. The Problem discussed is how morphological structures in English Zone and English book are revealed. In order to find out the answer, morphological structure in English textbook for senior high school on tenth grade student is used. From the analyzes, it is found that the aspect of morphological structures are revealed in every word. The student learnt the morphological structures from the easier to the complicated one.
\end{abstract}

Keywords: Morphological structures, morphology, prefix, infix, suffix, inflectional, derivational

\section{INTRODUCTION}

English language is a tool to communicate with other people, to share an idea or thought, feeling, and opinion. English language is also a system that has a symbol or signal consist of sound, word sentences, and discourse. From those symbols, people make agreement at the meaning of word, learn together that words and use it to communicate with other people in exchanging the information in economics, politics, education and others important aspects.

Concerning on the description of the language itself, Kumaravadivelu stated that a definition of language is always implicitly or explicitly, a definition of human being in the world (2006). That is because language permeates every aspect in human experience, and creates as well as reflects images of that experience, It is almost impossible to imagine human life without it.

He also added that, from one perspective, a study of language is basically a study of its system and subsystems. Chomsky who has persuasively demonstrated that language as system is amenable to scientific analysis and, in doing so, he has elevated our ability to deal with language as system to a higher level of sophistication.

English is increasingly being used as a tool for interaction among non-native speakers. Well over one half of the one billion English speaker of the world learned English as a second (or foreign) language. Most English language teacher across the globe ate non-native English speaker, which means that the norm is bilingualism. English has become a tool for international communication in transportation, commerce, banking tourism, technology, diplomacy, and scientific research. (Kachru, 2005; McKay, 2002)

English language is usually valued highly as a tool for upward mobility. But in many countries, English is a required subject in secondary schools and higher education institutions. In Indonesia, English has an important role that is to be the foreign language. Since it is a foreign language, English is only taught in schools or in other educational institutions such as English courses. The community does not use English as a means of communication. Therefore access to this language is limited.

In English classroom, textbooks are used in different ways in language programs. For example, a reading textbook might be the basic for a course on reading skills, providing both a set of reading texts and exercises for skills practice (Richards, 2001: 254). The students learn English grammars and sills from the book as the source. Additionally, they learn how to use the language in a contest. An English textbook has an important role in the classroom.

According to O'Neill, concerning on the use of textbook itself, it is important that textbooks should be so designed and organized that a great deal of improvisation and adaptation by both teacher and class possible ("107"). Moreover, since language is an instrument for generating what people need and want to say spontaneously, a great deal must depend on spontaneous, creative interaction in the classroom. Textbooks can help to bring this about. Whether one believes that textbooks ate too flexible and biased to be used directly as instructional material or that they actually help teaching and learning, there can be no denying the fact that 
textbooks still maintain enormous popularity and are most definitely here to stay.

Another reason for using that the textbooks we had selected for the course was their appearance and the quality of their presentation. In Indonesia, English textbook for senior high school student is based on schools-based curriculum dealing with four skills, listening, speaking, reading, and writing, and components, vocabulary, spelling grammar, and pronunciation. Those skills and components ate learned by the students in the class through a textbook.

One of the language component discussed in English textbook is grammar. In this research, there are two English textbook that provide grammar for senior high school in learning English are English and English Zone book. The English book consists of 312 pages with 10 units. It has description of the skills and language components. Each unit consists of 3 grammatical items that are connected to the topic. Each grammatical item is provided in table for an explanation. There are grammar exercises for students in every unit and grammar reviews in every five units.

The book is written by Utami Widiati, M. A, Ph.D $(\mathrm{Ed})$, she is an English lecturer of literary Faculty in Univesitas Negeri Malang. English book is published in 2009 and used by many senior high schools over the cities. This book is also be a best seller because it contents of many aspects, such as; listening, pronunciation, speaking, grammar focus, reading, suffix, prefix, and writing.

The English Zone book consists of 181 pages with 6 units. It has description of the skills and language component. Each unit consists of 2 until 3 grammatical items that connected to the topic. Each grammatical item is provided in table for an explanation. There are exercises for students and grammar review in every unit. The book is written by Eka Mulia Astuti, she is an English teacher and trainer. The book is published in 2006. It contains of reading text types, gambits, cross cultural understanding, grammar and opportunities to develop writing skills.

This research focuses on how the aspect of morphological structures in English book and English Zone book. The sequence that explained in English book are about To Be, The simple present tense, Prefix mis-, The present continuous tense, The future continuous tense, Suffix -ous, The simple future tense 'will/shall', The simple future tense 'going to' , Premix un-, The simple past tense, The past continuous tense, Suffix -ness, Imperative, Verb of perception, Prefix re-, Singular and plural nouns, Question tags, Suffix -ity, Pronouns, Reflexive pronouns, Suffix -ion, The present perfect tense, The present perfect continuous tense, Suffix able, Adjective order, Degree of comparison, Suffix -less, Modal (present), Modal (past), and Suffix -y.

The sequence that explained in English Zone book ate about Possesive form, WH-Question, Modals, Simple past tense, Past continuous tense, Imperative sentences, Adverbs of manner, Comparisons, Past perfect tense, Past forms, Adjectives, Order of adjectives, Reported speech, and Reported question.

Based on my observation, conducting by curriculum dealing with four skills; listening, specking, reading, and writing which consist of many aspects that must be studied further so that the student understands of those aspects can be more understandable. Besides, the morphology aspects that will be examined are only limited of the derivation word of adjective, noun, inflectional suffixes, and inflectional prefixes.

In Indonesia, English textbook for senior high school students is based on school - based curriculum dealing with four skills; listening, speaking, reading and writing, and components; vocabulary, spelling, grammar, and pronunciation. Those skills and components are learned by the students in the class through a textbook.

The reason why this research only focuses on the concept of morphology is because morphology is the aspect of language concerned with the internal structure of words, and languages very in the extent to which they rely on morphological structures and nowadays especially in schools curriculum either in classroom activity or textbook-oriented method, the teacher only teaches the material of grammar structures systematically. That's why the research tries to dig up further about morphological structures that hidden inside the grammatical pattern in English book for senior high school student.

\section{THEORETICAL REVIEW}

\section{The Concept of Textbook}

In language teaching, each lesson in the textbook should stand for a set of skills, a set of language patterns, and associated vocabulary first learnt in speech and then tested and exercised in the reading of a text and in the attached exercises. To make the best use of time in the classroom and to avoid unintended repetition or neglect of essential language patterns, the teacher is wise to have a textbook.

The component of textbook, they are: tasks, practical exercises, examples, reading texts and grammar focus. Majority of textbooks provided are in accordance with current curricula and syllabuses. Textbooks are available for almost all grades and 
subjects (with the exception of certain technical and vocational areas).

Kim and Hall (2002:3) state that textbook plays an important role in English Language Teaching (ELT), particularly in the English as a foreign language (EFL) classroom where it provides the primary from of linguistics input. They also add that textbook can also be used as a tool to initiate learning activities both the teacher and the student. Even though Werner (1995) says that it is also necessary to realize that no commercial textbook will ever be a perfect fit for a language program.

Besides, the writer of the textbook is generally concerned to produce a text that teacher will find innovative, creative, relevant to their learners needs, and that they will enjoy teaching from (Richard, 2001 : 257). The writer of the textbook has to condense; he cannot print everything in his book which the teacher should teach, it would become too thick and unmanageable; and in any case, he can never forecast what will happen in this or that class, or what the circumstances of a particular lesson will be. Since textbook holds important functions in language teaching, it should provide learners with the access of an extended usage of the target language.

Giroux explains that book is essential as teacher's role in the classroom. Book is a backbone of the materials. It is the media of subjects that student learn and apply their thinking abilities through knowledge and activities. By using the data and materials, students get a deeper understanding of the basic ideas that drive theories of the discipline (102).

Based on Byrd (1995) opinion, there are two factors that involved in the development of commercial textbooks: those representing the interests of the author, and those representing the interests of the publisher.

The second basic reason for using the particular textbooks we had chosen was that the books made it possible for learners who, for various reasons, had missed the lessons to catch up. They also made it possible for the class to prepare in advance for lessons. In my opinion it is important that textbooks should be so designed and organized that a great deal of improvisation and adaptation by both teacher and class is possible.

The third reason for using the textbook we had selected for the course was their appearance and the quality of their presentation. This is still one of the least discussed reasons for using textbooks. Textbooks can at best provide only a base or a core of materials. They are the jumping-off point for teacher and class. They should not aim to be more than that. Textbooks, if they are to provide anything at all, can only provide the prop or framework within which much of this activity occurs.

The same opinion comes from Brown about textbook. Student often feel more positive about textbook than some teachers. For them, the textbook is reassuring, it allows them to look forward and back, to give them a chance to prepare for what is coming and reviews what they have done. Now that, books tend to be much more colorful than in the old days, student enjoy looking at the visual material in front of them (117).

Krashen also states that the English textbook should have a natural sequence of subject or lesson so that the student could comprehend and learn easily. Moreover, it is not only students but also teachers need a textbook. For teachers, textbooks have many advantages. In the first place, textbooks have a consistently syllabus and vocabulary will have chosen with care. Good textbooks have a range of reading, listening material and grammatical items to back them up. They have dependable teaching sequences and, at the very least, they offer teachers something to fall back on when they run out of ideas of their own (118).

Textbook, like any other medium, have inherent limitations. The authors of textbooks must make it clear what those limitations are: for example, whether or not the textbook is intended as a selfstudy tool or aid, or for classroom use by a teacher and a group of learners. Most of all, the authors and creators of textbooks must abandon any claim that their products are anything more than basic tools (O’neill, 1982: 110-111).

Haines (1996:27) characterizes differences between past and current trends in English language textbooks. Textbooks ate used in different ways in language program. For example, a grammar textbook might serve as a reference book and provide examples as well as exercises to develop grammatical knowledge.

While Richards (2003: 254-255) adds the argument of principal advantages on the use of textbook:

1. They provide structure and a syllabus for a program.

2. They help standardize instruction.

3. They maintain quality.

4. They provide a variety of learning resources.

5. They are efficient.

6. They can train teachers.

7. They are visually appealing. 
8. They can provide effective language models and input.

This argument is supported by O'neill (1990) who argues that textbooks make it possible for students to review and prepare their lesson that textbooks are efficient in term of time and money, and that student can and allow for adaptation in improvisation.

Another argument is supported by O'neill (1989) who argued that materials have a hidden curriculum that includes attitudes toward knowledge, attitudes towards teaching and learning, attitudes toward the role and relationship of the teacher and student, and values and attitudes related to gender, society, etc.

From these arguments, a conclusion can be made. The use of textbooks is provides a lot of advantages both for the teachers and the learners of the language. Textbook not only has functions in assisting the teaching learning process, but it also has another purpose to facilitate the teachers and learners to make the most of the target language.

Understanding and realizing the importance and the crucial roles of textbook for EFL classroom, textbook itself should be good and appropriate to use. According to Berry, the textbook should consist of the authentic language forms. It means that in English textbook, it should consist of the authenticity of language use in conversation.

He adds that research into the adequacy of textbook to teach communication practices that ate reflective of authentic conversation has found that ELT textbook rarely include adequate or comprehensible explanations of how conversation works in English. It aims to help the learners to gain input on the exact situations where the language forms is used.

Kitao (1997) says a textbook should cover the cultural and information of the target language. He says that the cultural information included in English textbooks should be correct and recent. It should not be biased and should reflect background cultures of English. The purpose of cultural information included in English textbook is to give knowledge to the learners of the cultural information, do that it can provide a reference on why the language forms are used.

Brown says that textbook is one type of text, a book for use in an educational curriculum. Whether a curriculum or textbook is billed as functional, communicative, structural, or whatever, grammar and grammar sequencing is an issue. Grammar is the system of rules governing the conventional arrangement and relationship or word in a sentence. The components of words (prefixes, suffixes, roots, verb, and noun endings, etc) are indeed a part of grammar. Technically, grammar refers to sentence- level rules only, and not to rules governing the relationship among sentences (420).

As Diane Larsen-Freemen (2003) pointed out, grammar is one of three dimensions of language that are interconnected. Grammar gives the form or the structures of language, but those forms are literally meaningless without a second dimension. In other words, grammar tells us how to construct a sentence (word order, verb and noun systems, modifiers, phrases, clauses, etc). In such a view, grammar, according to Larsen - Freemen (2003), is a dynamic process and learners are called on to engage in what she called "grammaring".

\section{Morphological Structures}

The definition of morphology as Anderson say, Morphology, in linguistics, is the study of the forms of words, and the ways in which words are related to other words of the same language. Formal differences among words serve a variety of purposes, from the creation of new lexical items to the indication of grammatical structure. According to Aronof and Fudemen, In linguistics, morphology refers to the mental system involved in word formation or to the branch of linguistics that deals with words, their internal structure, and how they are formed. For example, Now consider the word reconsideration re- and -ation are both affixes, which means that they are attached to the stem. Affixes like re- that go before the stem ate prefixes, and those like -ation that go after ate suffixes. (2009).

Morphological structure is not just " string concatenation without hierarchy. According to Vikner, Morphology is the study of the structure and form of words in language or a language, including inflection, derivation, and the formation of compounds. At the basic lelvel, words are made of "morphemes". These ate the smallest units of meaning: roots and affixes (prefixes and suffixes).

According to Crystal (2003), inflectional morphology studies the ways word varies in their form iin order to express a grammatical contrast (as in the case of horses, where the ending marks plurality). According to the most usual division of subject, the fiels of morphology in general is divided into two major subfields: one concerned with processes of infliction (for example, with the role of English Verbal ending $-s$ or $-e n$ ), and the other with what are usually referred to as processes of wordinformation.

This latter field is the divided in turn into two smaller subfields, of which one in concerned with processes of derivation (for example, the derivation of 'generation' from 'generate' or Adjectival 'trying' from Verbal 'try'. 
Derivation is the process of adding affixes to or changing a base, thereby forming a word that may undergo further inflection or participate in different syntactic construction, constrasted with inflection.

For example: as informing Service from serve Song from sing

\section{Hardness from hard}

Inflektion morphology is the part of grammar that deals with the inflections of words.

Example: $\quad \operatorname{dogs}$ from $\boldsymbol{d o g}$

\section{Spoke from speak}

Native speakers recognize the morphemes as grammatically significant or meaning. For example, "schoolyard" is made of " school" + "yard", "makes" is made of "make" + a grammatical suffix "s", and "unhappiness" is made of "happy" with a prefix "un-" and suffix "-ness".

Inflectional occurs when a word has different forms but essentially the same meaning, and there is only a grammatical difference between them; for example, "make" and "makes". The "-s" is an inflectional morpheme. Inflectional morphology never involves a change of class. It occurs with nouns, pronouns and verb. In nouns, inflection marks plurality in regular nouns:

Pencil Pencils

Car

Cars

Inflectional morphemes: vary (or "inflect") the form of words in order to express grammatical features, such as singular/plural or past/present tense. For example: Boy and boys are two different forms of the "same" words; the choice between them, singular vs. plural, is a matter of grammar and thus the business of inflectional morphology (Crystal, 1991:90).

Derivation is the formation of a new word from another word. Derivation makes a word with a clearly different meaning: such as "unhappy" or "happiness", both from "happy". The "un-" and "ness are derivational morphemes. Normally a dictionary would list derived words, but there is no need to list "makes" in a dictionary as well as "make".

English has a number of adjectives of the type un $\mathrm{X}$ able, adjectives that contain the prefix un- and the adjectivising suffix -able, e.g unlockable or undoable. Many of these adjectives are ambiguous. If a door is unlockable, it may either mean that it cannot be locked (it is not lockable).
We will take the two different interpretations of unlockable to be the result of the adjectives in question having two different possible structural analyses. One in which the immediate constituents are $u n$ and lockable, (1a), and another one where the immediate constituents are unlock and -able, (1b):

(1) a. un-lockable $=[$ un $[$ lock-able $]]=$ that cannot be locked

b. unlock-able $=[[$ un-lock $]-$ able $]=$ that can be unlocked

In McGregor (2003: 59-61), it is argued that such analyses in terms of different hierarchical structures are not motivated, and that instead morphological structure is "string concatenation without hierarchy". He further says :

"It is difficult to construe un- as serving in a constituency relation to the larger unit unlock in [2b] - as serving a function within that whole (what would that function be?) - or to the larger unit unlock-able in [2a] . (Adapted from McGregor (2003:60)".

We fully realize that this use of "function" differs from McGregor's use above. Our use of "function" here is the one that is current in mathematics and formal semantics. This difference in terminology, however, should not obscure the fact that $u n$ - has a function also in McGregor's sense within unlockable, comparable e.g. to the "grammatical function" that a sentential negation has within a clause.

Regarding to the English book which is written by Utami Widiati (Ed), there are several suffixes that explained, they are: -y, -less, -ity, -ion, -ness, -ous. And also there are some prefixes to be described, such as; re-, and un-. Those parts of the morphological structures of affixes will be explained more clearly as follow.

In the following, the actual morphological analysis will only be sketched out. We will therefore simplify the formalization as much as possible, in order to be able to focus on the aspects that are crucial to this research.

As stated above that suffix -ity is kind of morpheme that form a word of adjective, but then We would like to capitalize on some facts that have often been noticed, namely that it is a property of the affix which word class it may combine with, and that it is a property either of the affix or of the stem what the resulting word class is. For instance, the suffix -ity combines only with an adjective and the result is always a noun: [Adj legal] + [ity] $[\mathrm{N}$ legality]. 
Thus, morphemes may be partitioned in morpheme classes according to their distributional properties. Such morpheme classes we will designate by their subcategorisation frame. A morpheme like _ity will be associated with a lexical entry containing the categorical information shown in (3):

(3)-ity : Aff, [N Adj___ ]

The frame notation [N Adj _ _ ] means that the entity in question (here -ity) may be incserted at the place indicated by the underscore (i.e. immediately following an adjective) and that Adj + -ity make up a new unit belonging to the class N. Example of partial lexical enties for other types of morphemes:

(4)a. -ableV : Aff, [Adj V

b. -ableN : Aff, [Adj N__ ]

c. -ify : Aff, [V N__ ]

d. re- : Aff, [V__ V]

e. unA- : Aff, [A _ A $]$

f. unV-: Aff, [V__ V ]

The word formation processes involving the affixes mentioned in (3) and (4) may be described by the rewrite rule in (5).

As shown in lesson 5 of English book, it it clearly shown that there is prefix re-, concerning on this, Lieber ( 2004 : 147), this analysis explains why reonly combines with verb that imply a result, and that this result may not be 'finite, fixed or permanent'. Verbs like yawn or push do not imply result-states, and therefore there is no *reyawn or *repush. Similarly, there is no *reeat the apple because the result-state cannot be obtained again.

It is worth stressing that such an analysis only work if the morphological element are parts of a hierarchical structure. The meaning of $r e$ - is a semantic function that takes the meaning of classify as argument, not the meaning of class and not the meaning of -ify, In other words, re- is on the same level as classify, and class and -ify are one level further down.

In morphological structures, there are four stages that will be discussed in this research. They are:

*Present progressive (-ing endings of verb)

*Preposition (in, on)

*-s plurals ( regular plurals)

Name the Morphological structures that are present during stage I
*Irregular past tense (had, fell,sat,swam,saw)

*-s possessives

*Uncontractible copula (the full form of the verb ' to be' when it is the only verb in a sentences [links place, modifier, and noun] (are, is, am)

Name the Morphological structures that are present during stage II

*Articles

*Regular past tense (-ed endings on verbs)

*Third person regular past tense)

Name the Morphological structures that are present during stage III

*Third person regular present tense

*Uncontractible auxiliary (the full form of the verb 'to be' when it is an auxiliary verb in a sentence)

*Contractible copula ( the shortened form of the verb 'to be' when it is the only verb in a sentence)

*Contratible Auxiliary ( the shortened form of the verb 'to be' when it is an auxiliaru verb in a sentence)

Name the Morphological structures that are present during stage IV

For each part of the stage is fully shown in two books as the data sources to this research and will be analyzed in the following chapter based on the materials that have been chosen.

\section{METHODOLOGY}

Method is specific research technique. The method used in this research is the qualitative descriptive method. The research describes and analysis how the aspect of morphological structures in English Zone and English textbook are revealed for senior students.

Besides, to justify the differences from those books, the writer also uses the theory of triangulation in order to see the result in making sure about the data. The purpose of triangulation theory in qualitative research is to increase the credibility and validity of the results. Several scholars have aimed to define triangulation throughout the years.

- Cohen and Manion (2000) define triangulation as an "attempt to map out, or explain more fully, the richness and complexity of human behavior by studying it from more than one standpoint." 
- Altrichter et al. (2008) contend that triangulation "gives a more detailed and balanced picture of the situation."

- According to O'Donoghue and Punch (2003), triangulation is a "method of cross-checking data from multiple sources to search for regularities in the research data ."

- According to Erina Audrey (2013) "Triangulation also crosschecks information to produce accurate results for certainty in data collection".

The aim of descriptive study is to make a description and a picture in a systematic and accurate manner on conclusion which is applied in real life. Kumar states, "The study is classified as qualitative if: the purpose or aim of the study is primarily to describe a situation, phenomenon, problem or event; the information is gathered through the use of variables measured on nominal or ordinal scales (qualitative measurement scales)...'(10). In this case, the research method used in this research is qualitative study to obtain data from an English textbook titled.

In qualitative research, the researcher is the primary research instrument. First, researchers themselves collect the data, by directly observing or interviewing the participants, for example. They can also collect a wide range of dta and begin to think about it immediately, allowing them to clarify ideas promptly for accuracy of interpretation. ( Merriam, 2002)

The researcher took the data from the book of English book and English Zone for senor high school first grade student. The English book is composed by Utami Widiati, M.A, Ph.D. (Ed), published by Bailmu in 2009. It consists of 10 units and each unit consists of 2 grammar focus and 2 reading texts.

The English Zone book is composed by Eka Mulia Astuti, published by Erlangga in 2010. It consists of 6 units and each unit consists of 2 grammar focus and 2 reading texts that are analyzed.

After reading the data sources, the aspect of morphological structures from the content of the books are noted down by analyzing the words in grammar focus and reading texts as parts of the morphological structures concerning on the derivational and inflectional. Then, the details of this aspect in morphology focus are listed in the explanation.

The following are the steps to analyze the data:

a. The data which have been listed are compared for analyzing the aspect of morphological structures.

b. After that, the data are viewed from the sources to identify how morphological structures are revealed.

c. From this analysis, how the morphological structures are revealed could be explaned.

\section{FINDING AND DISCUSSION}

Suffixes are the most common, and English uses them. For example, in English Zone textbook there is a chapter that analyzed about simple past tense both in grammar focus and in its reading text.

Table 1. Grammar Focus and Reading Text of English Zone book.

\begin{tabular}{|c|c|c|}
\hline \multirow[t]{2}{*}{ Name of Unit } & \multicolumn{2}{|l|}{ TOPICS } \\
\hline & Grammar Focus & Rending Text \\
\hline \multirow[t]{2}{*}{ Unit 2} & Simple Past Tense & $\begin{array}{l}\text { The women who caused the } \\
\text { invention of Band-Aid }\end{array}$ \\
\hline & Past Cont. Tense & Cantika's diary \\
\hline \multirow[t]{2}{*}{ Unit 3} & Imperative Sentences & Camera \\
\hline & Adverbs of Manner & \\
\hline \multirow{3}{*}{ Unit 4} & Comparisons & Gatotkaca \\
\hline & Past Perfect Tense & Hercules \\
\hline & Past Forms & Nyai Lara Kidul \\
\hline
\end{tabular}

Grammar focus : Simple Past Tense (Unit 2) 
In English, derivational may appear either prefixes suffixes:

$$
\text { Un }+ \text { fortunate }+ \text { ly =unfortunately }
$$

Or to inflect the plural of noun is made by adding $-s$

Here are some examples:

$\begin{array}{lll}\text { Week } & \rightarrow & \text { weeks } \\ \text { Passenger } & \rightarrow & \text { passengers } \\ \text { Hour } & \rightarrow & \text { hours } \\ \text { Day } & \rightarrow & \text { days }\end{array}$

( English Zone book, chapter 2: page 36-57)

Grammar focus: Imperative Sentences ( Unit 3 )

The Inflectional of suffix $-s$ :

$\begin{array}{lll}\text { Manner } & \rightarrow & \begin{array}{l}\text { manners } \\ \text { includes }\end{array} \\ \text { Include } & \rightarrow & \text { utensils } \\ \text { Utensil } & \rightarrow & \text { cultures } \\ \text { Culture } & \rightarrow & \text { standards } \\ \text { Standard } & \rightarrow & \text { noises } \\ \text { Noise } & \rightarrow & \\ \text { Elbow } \rightarrow & \text { elbows } & \end{array}$

The inflectional suffixes of past tense is made by adding -ed

For examples :

$\begin{array}{ll}\text { Eat }+ \text { ing } & =\text { eating } \\ \text { Interest+ ing } & =\text { interesting } \\ \text { Cough+ ing } & \text { = coughing } \\ \text { Sneeze+ ing } & \text { = sneezing } \\ \text { Blow + ing } & =\text { blowing } \\ \text { Leave + ing } & =\text { leaving } \\ \text { Return+ ing } & \text { = returning }\end{array}$

Or affixation involving both prefixation and suffixation :

$$
\text { Un }+ \text { become }+ \text { ing }=\text { unbecoming }
$$

There is also suffix which commonly chane the class of the word to which they are attached.

For example, word ending -ize tend to be verb :

$$
\text { - Apologize }
$$

Word ending in $-l y$, tend to be adverbs:

$$
\text { - Excessively }
$$

\section{Reading Text: Camera ( Unit 3 )}

Suffixation the plural of a noun is made by adding $s$ :

$\begin{array}{ll}\text { Camera } & \rightarrow \text { cameras } \\ \text { Video } & \rightarrow \text { videos } \\ \text { Hand } & \rightarrow \text { hands } \\ \text { Picture } & \rightarrow \text { pictures } \\ \text { Len } & \rightarrow \text { lens } \\ \text { Scene } & \rightarrow \text { scenes } \\ \text { Adjustment } & \rightarrow \text { adjustments } \\ \text { Setting } & \rightarrow \text { settings } \\ \text { Press } & \rightarrow \text { presses } \\ \text { Clip } & \rightarrow \text { clips } \\ \text { Option } & \rightarrow \text { options } \\ \text { Application } & \rightarrow \text { applications }\end{array}$

Suffixation of the gerund is made by adding -ing :

Follow $\quad+$ ing $=$ following

Save +ing = saving

Take +ing $=$ taking

Use $\quad+$ ing $=$ using

Lock +ing = locking

Word ending in $-\mathrm{ly}$, tend to be adverb:

$$
\text { - Digitally }
$$

Word ending -ate tend to be verb:

$$
\text { - Activate }
$$

Word ending -or tend to be noun:

$$
\text { - Indicator }
$$

Word ending in -able tend to be adjective:

$$
\text { - Available }
$$

Grammar Focus: Adverbs of Manner ( Unit 3 )

The Inflectional of suffix $-s$ :

$\begin{array}{lcc}\text { Example } & \rightarrow \text { examples } & \\ \text { Pan } & \rightarrow \text { pans } & \\ \text { Word } & \rightarrow \text { words } & \\ \text { Adverb } & \rightarrow \text { adverbs } & \\ \text { Edge } & \rightarrow \text { edges } & \\ \text { Minute } & \rightarrow \text { minutes } & \\ \text { Change } & \rightarrow \text { changes } & \\ \text { Happen } & \rightarrow \text { happens } & \\ \text { Words ending in } & - \text { ly, tend to be adverbs: } & \\ \text { Slightly badly } & \text { automatically } & \\ \text { Comfortably } & \text { beautifully } & \text { truly } \\ \text { Lightly } & \text { easily } & \text { fully }\end{array}$

( English Zone, Chapter : page 60-83)

Grammar Focus: Comparations (Unit 4)

A regular pattern of suffixation with -er and -est, are comparative and superlative forms of adjectives belong to inflectional rather than derivational morphology.

Here are the examples :

Positive Comparative Superlative 


\begin{tabular}{|c|c|c|}
\hline Tall & taller & the tallest \\
\hline Large & largerthe largest & \\
\hline Happy & happier & the happiest \\
\hline Pretty & prettier & the prettiest \\
\hline \multicolumn{3}{|c|}{ The Inflectional of suffix $-s$ : } \\
\hline Comparison & $\rightarrow$ & comparisons \\
\hline Show & $\rightarrow$ & shows \\
\hline Thing & $\rightarrow$ & things \\
\hline Point & $\rightarrow$ & points \\
\hline Difference & $\rightarrow$ & differences \\
\hline Sentence & $\rightarrow$ & sentences \\
\hline Game & $\rightarrow$ & games \\
\hline Other & $\rightarrow$ & others \\
\hline
\end{tabular}

Suffixes that form adjective in $-e d,-f u l$, - ous and $-y$

Here are the example:

Captured

Famous

Useful

Powerful

Beautiful

Pretty

Suffixation as derivational morphology:

Like + ness $=$ likeness

Grammar focus : Past Perfect Tense (Unit 4) :

Word ending in the morpheme -ity tend to be noun.

$$
\text { - Activity }
$$

The suffixes of regular past participle is made by adding $-e d$.

Here are the examples :

\section{Completed}

Compared

Suffered

Passed

Killed

Word ending in $-l y$, tend to be adverb :

Usually Finally

\section{Grammar Focus : Past Forms ( Unit 4 )}

The inflection of verbs or nouns are made by adding $-s$ or $-e s$

\section{Example :}

Expresses (verb)

Exists (noun)

Teaches (verb)

Novels (noun)

Means (verb)

Words ending in the morphemes -ion, and -ment tend to be nouns.
Situation

Action

Punishment

\section{Reading Text : Gatotkaca ( Unit 4 )}

Words ending in - $l y$, ten to be adverbs.

Here are the examples

Naturally
Sadly
Accordingly
Miraculously
Fully
The inflection of
Kinds
Gods
Sandals
Clothes
Weapons
Derivational word
:
Powerful
Words ending in
nouns.
For example :
Embarrassment
Kingdom
Laughter
Commander

\section{Reading text : Hercules (Unit 4)}

Suffixation of derivational morphology include of the words ending in -ous, and -less that tend to be Adjective.

Here are the examples:

Jealous

Mischievous

Speechless

Inflection of plural nouns and verb are made by adding $-\mathrm{s}$.

Here are the examples :

Tasks (noun)

Apples (noun)

Maidens (noun)

Shoulders (noun)

Years (noun)

Knows (noun)

Suffixation :

$\begin{array}{ll}\text { Firm +ly } & =\text { firmly } \\ \text { Final +ly } & =\text { Finally } \\ \text { Immediate +ly } & =\text { immediately } \\ \text { Slow =ly } & =\text { slowly } \\ \text { Cunning + ly } & =\text { cunningly } \\ \text { Quiet }+ \text { ly } & \text { = quietly }\end{array}$


Tight =ly = tightly

Word ending in -ment tend to be noun :

Astonish + ment $=$ astonishment

Suffixation -er, belongs to inflectional adjectives :

Stronger

Longer

Reading text : Nyai lara Kidul (Unit 4)

Suffixes $-e d$ as Regular Past forms

$\begin{array}{llc}\text { Cried } & \text { looked bagged jumped } \\ \text { Remembered } & \text { said } & \text { started } \\ \text { Praised } & \text { forced flowed twisted } \\ \text { Screamed } & \text { walked ended } & \text { opened } \\ \text { Turned } & \text { reached pulled looked } \\ \text { Smiled } & \text { noded } & \end{array}$

Suffixes that form adjective are made by adding $-l y$, -ish, -ful, and-ous.

Here are the examples:

Lovely

Yellowish

Beautiful

Powerful

Wonderful

Jealous

Hideous

Prefixes that form nouns:

Kilo + meter $=$ kilometer $($ noun $)$

Mix + fortune $=$ misfortune $($ noun $)$

Or affixes involve both prefix and suffix:

Un + believe + able = unbelievable

$\mathrm{re}+$ mark + able $=$ remarkable

Suffixes $-s$ as plural nouns:

hours soldiers demons

Scales ladies attendants

Eyes pearls descendants

Lips petals troops

Wives creatures kings

Word spirits

Suffixes $-l y$ that form adverbs:

Clearly

Slowly

Smelly

Hardly
Suffixes ion that form nouns:

Secretion

Meditation

Reading text : Romeo and Juliet (Unit 4)

Suffixes $-s$ as plural nouns:

$\begin{array}{ll}\text { Friends } & \text { days } \\ \text { Streets } & \text { contents } \\ \text { Citizens } & \text { hours } \\ \text { Wives } & \text { drugs } \\ \text { Tears } & \text { hands } \\ \text { walls } & \end{array}$

Derivational morphology that involves suffixation:

life + less $=$ lifeless

Derivational morphology that only involves prefixation:

Un + welcome = unwelcome

Or affix that involves both prefix and suffix:

Un + sheath + ed + unsheathed

Words ending in $-l y$, tend to be adverbs.

Here are the examples:

Deadly

Quickly

Desperately

Word ending in -ment and -ion, tend to be nouns.

Examples:

Banishment

Confession

Admission

(English Zone, 2010: page 84 - 114) 
The Aspect Of Morphological Structures In English Textbook For Senior High School On Tenth Grade Student's

Table 2. Grammar Focus and Reading Text in English book.

\begin{tabular}{|l|l|l|}
\hline \multirow{2}{*}{ Name of Unit } & \multicolumn{1}{|c|}{ TOPICS } \\
\cline { 2 - 3 } Unit 1 & \multicolumn{1}{|c|}{ Grammar Focus } & \multicolumn{1}{c|}{ Reading Text } \\
Unit 2 & $\begin{array}{l}\text { To Be } \\
\text { Simple Present Tense } \\
\text { Present Cont. Tense } \\
\text { Future Cont. Tense } \\
\text { Simple Future Tense } \\
\text { 'Will/Shall' and 'Going to' }\end{array}$ & $\begin{array}{l}\text { Educational technology } \\
\text { Moving to The Moon } \\
\text { Unit } 6\end{array}$ \\
Unit 7 & $\begin{array}{l}\text { Singular and Plural Nouns } \\
\text { Question Tags } \\
\text { Pronouns } \\
\text { Reflexive Prounouns }\end{array}$ & $\begin{array}{l}\text { Newspaper and Megazine } \\
\text { Unique Customs }\end{array}$ \\
\hline
\end{tabular}

Grammar Focus: To Be (Lesson 1)

Suffixes $-s$ as plural nouns and verbs:

Exist (verb)

Statements (noun)

Sentences (noun)

Questions (noun)

Contractions (noun)

Prefix that from adjective:

Ir + regular $=$ irregular

There is also an example of suffix which commonly changes the class of the word to which it is attached:

Beauty $(n)+$ ful = beautiful $(\operatorname{adj})$

Grammar Focus: The Simple Present Tense (Lesson 1)

Suffixes $-s$ as plural nouns:

Actions

Verbs

Statements

Suffix -ence that form nouns:

Existence Reliance

Intelligence

Reading Text: Educational Technology (Lesson 1)

Words ending in -ical, $-e d$, $-a l$, and $-i c$, tend to be adjectives

Here are the example:

Technological

Mechanical

Systematic

Genetic
Medical

Individualized

Traditional

Derivational morphology that involve suffixation:

Effective + ness $=$ effectiveness

Suffixes $-s$ as plural nouns:

Innovations

Breakthroughs

methods

Strips

Picture

Machines

Devices

Students

Steps

Means

Changes

Memories

fads

technologies

effects

predecessors

barriers

researchers

studies

ways

hopes

communications

Word ending in -tion, tend to be noun.

Here are the examples:

Motion

Instruction

Revolution

Revolution

Information

Attention

Word ending in $-y$, tend to be noun:

Illusory

Biochemistry

Memory

(English, 2009 page 2-28)

Grammar Focus: The Present Continuous Tense (Lesson 2) 
Word ending as suffixes in -ous, and -ive, tend to be adjectives.

Here are the examples:

Continuous

Nervous

Ridiculous

Progressive

Relative

Suffixes $-s$ as plural nouns and verbs:

Actions

Words

Exists

Grammar Focus: The Future Continuous Tense (Lesson 2)

Derivational morphemes can be selective about what they 'ill combine with.

Thus the suffix from the present participle is made by adding -ing.

Here are the examples:

$\begin{array}{ll}\text { Talk }+ \text { ing } & =\text { talking } \\ \text { Play }+ \text { ing } & =\text { playing } \\ \text { Do }+ \text { ing } & =\text { doing } \\ \text { Rain }+ \text { ing } & =\text { raining } \\ \text { Use }+ \text { ing } & =\text { using } \\ \text { Go }+ \text { ing } & =\text { going } \\ \text { Speak + ing } & =\text { speaking } \\ \text { Write }+ \text { ing } & =\text { writing } \\ \text { Happen + ing } & =\text { happening }\end{array}$

Suffixes $-s$ or $-e s$ as verb

Knows

Understands

Expresses

\section{Reading Text: Mardi Gras History (Lesson 2)}

The suffixes of plural noun is made by adding $-s$.

Here are the examples:

$\begin{array}{lcl}\text { Balls } & \text { themes } & \begin{array}{l}\text { superstars } \\ \text { days }\end{array} \\ \text { Parties } & \text { parades } & \\ \text { Places } & \text { costumes } & \\ \text { Americans } & \text { nets } & \\ \text { New Orleanians } & \text { wagons } & \\ \text { Streets } & \text { floats } & \\ \text { Celebrations } & \text { clubs } & \\ \text { Societies } & \text { policies }\end{array}$

$\begin{array}{ll}\text { Functions } & \text { organizations } \\ \text { Cars } & \text { members }\end{array}$

Words ending in $-l y$, tend to be adverbs.

Here are the examples:

Really

Principally

Properly

Royally

Secretly

Recently

Completely

Word ending in the morphemes -ment, -ion, -ty,-ism, -ness, and-ship, tend to nouns.

Here are the example:

$\begin{array}{ll}\text { Government } & \text { snobbishness } \\ \text { Management } & \text { membership } \\ \text { Organization } & \text { royalty } \\ \text { Procession } & \text { exclusivity } \\ \text { Administration } & \text { hospitality } \\ \text { Interruption } & \text { Patriotism }\end{array}$

Words ending in -able, -ous, -ed, -ic, -ful,-al andive, tend to be adjectives.

Here are the examples:

Charitable

Hilarious

Characteristic

Political

Official

Hand-decorated

Secretive

Beautiful

Derivational morphology that involve prefixation:

$\begin{array}{ll}\mathrm{Un}+\text { rest } & =\text { unrest } \\ \mathrm{Re}+\text { turn } & =\text { return } \\ \mathrm{Ire}+\text { sistible } & =\text { irresistible }\end{array}$

Or affixation involving both prefix and suffix:

Anti + discriminate + ion $=$ anti-discrimination

(English, page 29-52)

Grammar Focus: The Simple Future Tense 'Will/Shall and 'Going To'

(Lesson 3)

Suffix -ion tend to be noun. 
Here are the examples:

Decision

Prediction

The suffixes of plural is made by adding $-s$

Here are the example:

Situation
Events
Weeks
Predictions
Facts
Hours
Kitties
Intentions
Conversations
Word ending in -ly tend to be adverb:
Really

Derivational morphology that involves prefixation:

$$
\text { In }+ \text { formal = informal }
$$

Reading text: Study Tour ( Lesson 3)

The suffixes of plural noun is made by adding $-S$

$\begin{array}{ll}\text { Students } & \text { forks } \\ \text { Experiences } & \text { spoons } \\ \text { Readers } & \text { glasses } \\ \text { Hours } & \text { plates } \\ \text { Waiters } & \\ \text { Napkins } & \end{array}$

The suffixes of $-f u l$, -ous and $-a l$, are tend be adjectives.

Here are the examples:

Useful

Advantageous

Professional

Words ending in -ion tend to be nouns.

Station

Information

Here are the example of affixation involving both prefix and suffix:

Un + forget + able = unforgettable

\section{Reading text: Moving the Moon ( Lesson 3)}

The suffixes of plural noun is made by adding $-s$.

Here are the examples:

$\begin{array}{lll}\text { Decades } & \text { samples } & \text { buildings } \\ \text { Series } & \text { things } & \text { spacesuits } \\ \text { Articles } & \text { rocks } & \text { rockets } \\ \text { Scientists } & \text { elements } & \text { passengers } \\ \text { Plans } & \text { metals } & \text { colonies } \\ \text { Cities } & \text { colonists } & \text { times } \\ \text { Missions } & \text { ways } & \text { settlers } \\ \text { Humans } & \text { workers } & \text { legs } \\ \text { Beds } & \text { tables } & \text { tools } \\ \text { Windows } & \text { locations } & \text { houses } \\ \text { Tunnels } & \text { cities } & \text { trays } \\ \text { Plants } & \text { batteries nights } & \\ \text { Minerals } & \text { telescopes } & \text { bjects } \\ \text { Tourists } & \text { effects } & \end{array}$

Words ending in -ion, -ty and -ment tend to be nouns:

\section{Condition \\ Fascination \\ Operation \\ Location \\ Electricity \\ Possibility \\ Equipment \\ Experiment}

Suffixes -able and $-f u l$ are tend to be adjectives.

Valuable

Suitable

Inflatable

Powerful

Derivational morphology that involves prefixation.

Here are the examples:

$$
\begin{array}{ll}
\mathrm{Re}+\text { turn } & =\text { return } \\
\mathrm{Re}+\text { cycle } & =\text { recycle } \\
\mathrm{Re}+\text { place } & =\text { replace } \\
\text { in }+ \text { habitant } & =\text { inhabitant } \\
\text { un }+ \text { happy } & =\text { unhappy } \\
\text { Or affixation involving both prefix and suffix: } & \\
\text { Un }+ \text { count }+ \text { able } & =\text { uncountable }
\end{array}
$$

\section{Reading Text: Thailand Culture (Lesson 3)}

The suffixes of plural noun is made by adding $-S$

$\begin{array}{lll}\text { Peoples hundreds } & \text { festivals } \\ \text { Admonitions } & \text { years } & \text { relations } \\ \text { Parents } & \text { rites } & \text { customs } \\ \text { Elders } & \text { ceremonies } & \text { necessities } \\ \text { Teachers } & \text { feasts } & \text { utensils } \\ \text { Days } & \text { cities } & \text { areas }\end{array}$


Word ending in -ion, and -ment, tend to be noun;

Education

Civilization

Location

Celebration

Tradition

Advancement

Affixation involving both prefix and suffix.

Here are the examples:

Un + mention + ed $=$ unmentioned

Un + count + able = uncountable

Word ending in -ive, and -al, tend to be adjectives:

Primitive

Traditional

(English, 2009: page 53-76)

Grammar Focus: Singular and Plural Nouns (Lesson 6)

When a noun means only one, it is said to be plural.

Here are the example:

\begin{tabular}{|c|c|c|}
\hline Book & $\rightarrow$ & books \\
\hline Pencil & $\rightarrow$ & pencils \\
\hline Boy & $\rightarrow$ & boys \\
\hline Day & $\rightarrow$ & days \\
\hline Roof & $\rightarrow$ & roofs \\
\hline Safe & $\rightarrow$ & safes \\
\hline \multicolumn{3}{|c|}{ Other example are: } \\
\hline \multicolumn{3}{|c|}{ Sugars } \\
\hline \multicolumn{3}{|c|}{ Coffees } \\
\hline Kinds & & \\
\hline
\end{tabular}

Grammar Focus: Question tags (Lesson 6)

Suffixes-ion, and -ment, tend to be nouns:

Confirmation

Agreement

Statement

The suffixes of plural noun is made by adding $-S$

Here are the examples:

Tags

Auxiliaries

Word ending in -ly tend to be adverbs.

Hardly

Barely
Rarely

Scarcely

Suffix -ity come from adjectives that can be changed into nouns, those mean state, quality or abnormality. For example, Zwicky discusses the case of -ity suffixation in English, which refers to as derivational.

\begin{tabular}{|c|c|}
\hline Able & ability \\
\hline Acceptable & acceptability \\
\hline Advisable & advisability \\
\hline Capable $\rightarrow$ & capability \\
\hline Continuous & continuity \\
\hline Durable $\rightarrow$ & durability \\
\hline Flexible $\rightarrow$ & flexibility \\
\hline Possible $\rightarrow$ & possibility \\
\hline
\end{tabular}

Reading Text: Newspaper and Magazine

The suffixes of plural noun is made adding $-s$

Here are the example:

$\begin{array}{lll}\text { Homes } & \text { letter } & \text { newspapers } \\ \text { Other } & \text { facts } & \text { section } \\ \text { Friends } & \text { words } & \text { Sundays } \\ \text { Neighbours } & \text { opinions } & \text { comics } \\ \text { News } & \text { comments } & \text { magazines } \\ \text { Stories } & \text { events } & \text { articles } \\ \text { Columns } & \text { candidates } & \end{array}$

Word ending in -ion, and-ment, to be nouns.

For instances:

$\begin{array}{ll}\text { Election } & \text { imagination } \\ \text { Edition } & \text { amusement }\end{array}$

Addition

Publication

Population

Selection

Fiction

The word ending in $-a l$, and -able, tend to be adjectives

Here are the example:

Editorial

Criminal

Material

Favorable

Affixation involving both prefix and suffix:

$\mathrm{Un}+$ favor + able $=$ unfavorable 
Inter + nation + al $=$ international

Word ending in $-l y$ tend to be adverbs:

Usually

Especially

Weekly

Monthly

Primarily

(English, 2009 page 149-174)

Grammar Focus: pronouns (Lesson 7)

Suffixes-s as plural noun and verbs:

$\begin{array}{ll}\text { Takes } & \text { designs } \\ \text { Sentences } & \text { residents } \\ \text { Objects } & \text { buys } \\ \text { Refers } & \text { ministers } \\ \text { Types } & \text { plants } \\ \text { Keeps } & \text { wishes } \\ \text { Wastes } & \text { exercise } \\ \text { Things } & \text { peaces }\end{array}$

Suffix -ion mean act, process, state or condition.

Here are example:

$\begin{array}{ll}\text { Abbreviate (verb) } \rightarrow & \begin{array}{l}\text { abbreviation (noun) } \\ \text { calculation (noun) }\end{array} \\ \text { Calculate (verb) } \rightarrow & \begin{array}{l}\text { Educate (verb) } \rightarrow \\ \text { education (noun) } \\ \text { Eradicate (verb) } \rightarrow\end{array} \\ \text { eradication (noun) }\end{array}$

Grammar Focus: Reflexive Pronoun (Lesson 7)

Words ending $-s$ tend to be verb of present tense.

Here are example:

Turns

Reflects

Bits

Medals

Reading Text: Unique Customs (Lesson 7)

Suffix $-s$ as plural nouns:

$\begin{array}{ll}\text { Animals } & \text { celebrations } \\ \text { Flowers } & \text { families } \\ \text { Ribbons } & \text { fireworks } \\ \text { Koreans } & \text { friends } \\ \text { Ancestors } & \text { parties } \\ \text { Gravers } & \text { beans } \\ \text { Sites } & \text { homes } \\ \text { Cakes } & \text { shrines }\end{array}$

spirits

Words ending in -ity and -ion, tend to be nouns :
Royalty

Protection

Derivational morphology that involves prefixation .

For example :

$\mathrm{Ex}+$ change $=$ exchange

\section{Reading Text ; The Thanksgiving Story ( Lesson} 7)

Suffix $-s$ as plural nouns ;

Pilgrims products

Members Europeans

Interests berries

Colonists plums

Indians friends

Natives hardships

Days letters

Ducks governors

Pastries presidents

Potatoes

Words ending in -al, -ous, -able, -ic, and -ful, tend to be adjective;

Here are the examples :

Traditional

Editorial

National

Religious

Poisonous

Notable

Patriotic

Beautiful

Words ending in $-l y$, tend to be adverbs :

Originally

Eventually

Newly

Securely

Finally

Words ending in -ance and -ion, tend to be nouns

Tolerance

Observance

Persecution

Celebration

Recognition

Obsession 
Affixation involving both prefix and suffix :

$\begin{array}{lllll}\text { Un } & + \text { like } & + & \text { ly } & =\text { unlikely } \\ \text { Un } & + \text { god } & + & \text { ly } & =\text { ungodly }\end{array}$

( English, 2009: page:175-204)

\section{CONSCLUSION}

After analyzing the data, the researcher concluded that the derivational words and inflectional prefixes and suffixes of grammar focus and reading text in English Zone book and English book had met the aspect of morphological structures in English textbook for senior high school students. The analysis of morphological structures in English Zone book and English book for ten grade students of senior high school started from the easier to the difficult one.

Best on my observation, to cross check the data concerning on what is needed about the curriculum that refers to the curriculum is by conducting the curriculum dealing with four skills; listening, speaking, reading, and writing which consist of many aspects that must be studied further so that the student's understanding of those aspects can be more understandable. Besides, the morphology aspects that will be examined are only limited of the derivation word of adjective, noun, inflectional suffixes, and inflectional prefixes.

In Indonesia, English textbook for senior high school student is based on school - based curriculum dealing with four skills; listening, speaking , reading, and writing, and components; vocabulary, spelling, grammar, and pronunciation. Those skills and components are learned by the students in the class through a textbook.

Besides, the writer has found that several comparisons between English Zone and English book in relation to the aspect of morphological structure. First, the English book which is written by Utami Widiati, contained some prefixes and suffixes in each lesson, For example, in Lesson 7 explains about suffix -ion and its meaning. It tells how to change the verb into noun in order to make suffix ion. On the other hand, in English Zone book which is published by Erlangga, there is no explanation about prefix and suffix in detail.

Second, the form of book content and systematic of writing between those books are slightly different. In addition, the writer also added the theory of triangulation to justify any form about the result of the comparison to make sure that there are differences from those books in relation to the morphological structures.

\section{BIBLIOGRAPHY}

Ackema, Pater, \& Neeleman, Ad. Beyond Morphology : Interface Condition on Word Formation. New York : Oxford University Press, 2004

Altrichter, H, Feldman, A, Posch, P. \& Somekh, B. Teachers investigate their work; An introduction to action research across the professions, Routledge.p. 147. ( $2^{\text {nd }}$ edition), 2008

Astuti, Eka Mulia. English Zone. Jakarta : Erlangga, 2006

Brown, H. Douglas. Principles of Language Learning and Teaching. $4^{\text {th }}$ ed. New York : Longman,2000

Carstairs, Andrew, \& McCarthy. An Introduction to English Morphology : Words and Their Structure. Ediburg Edinburg University Press, 2002

Cohen, L, \& Manion, L. Research methods in education. Routledge. P.254. ( $5^{\text {th }}$ edition $)$, 2000

Crystal, David. The Cambridge Encyclopedia of The English Language, $2^{\text {nd }}$ ed. Cambridge University press, 2003

Heigham , Juanita, \& A. Robert. Qualitative Research in Applied Linguistic : A Practical Introduction. United States : Palgrave Mac Millan, 2009

Kumaravadivelu, B. Understanding Language Teaching : From Method to Postmethod. London : Lawrence Erlbaum Associates, 2006

MBP, Abdurrahman. English in Use : Composition. Bogor : Sekolah Tinggi Agama Islam AlHidayah, 1012

O’Donoghue, T., Punch K. Qualitative Edicational Research in Action: Doing and Refkecting. Routledge. P.78, 2003

Richards, Jack C. Curriculum Development in Language Teaching. New York : Cambridge University Press, 2001

Stonham, T. Jhon. Combinatorial morphology, Philadelphia : John Benjamins Publishing Co, 1994

Thornbury, Scott. How to Teach grammar. London : Longman, 1999 
The Aspect Of Morphological Structures In English Textbook For Senior High School On Tenth Grade Student's

Widiati, Utami. English. Jakarta : Bailmu, 2009

Kitao, K, \& Kitao, K.S. Selecting and Developing Teaching/Learning Materials Internet TESL Journal \{electric journal\} November 18, URL:http://www.aitech.ac.JP/itesl/Articles/Kitao-Materials.htm.

\section{PROFIL PENULIS}

Ferdias Prihatnasari earned her Bachelor's degree from Department of English Languages and Literature, Nasional University Jakarta in 2010 and

later her Master's Degree in English Education from Indraprasta PGRI University Jakarta in 2014. Currently she is a lecturer at Bina Sarana Informatika University and she can be reached through ferdias.fps@bsi.ac.id 